The Historical Journal

http://journals.cambridge.org/HIS

Additional services for The Historical Journal:

Email alerts: $\underline{\text { Click here }}$

Subscriptions: Click here

Commercial reprints: Click here

Terms of use : $\underline{\text { Click here }}$

\title{
ORDER AND DISORDER IN EUROPE: PARLIAMENTARY AGENTS AND ROYALIST THUGS 1649-1650
}

\section{JASON T. PEACEY}

The Historical Journal / Volume 40 / Issue 04 / December 1997, pp 953 - 976

DOI: null, Published online: 08 September 2000

Link to this article: http://journals.cambridge.org/abstract S0018246X9700753X

How to cite this article:

JASON T. PEACEY (1997). ORDER AND DISORDER IN EUROPE: PARLIAMENTARY AGENTS AND ROYALIST THUGS 1649-1650. The Historical Journal, 40, pp 953-976

Request Permissions : $\underline{\text { Click here }}$ 
The Historical Fournal, 4o, 4 (1997), pp. 953-976. Printed in the United Kingdom

(C) I997 Cambridge University Press

\title{
ORDER AND DISORDER IN EUROPE: PARLIAMENTARY AGENTS AND ROYALIST THUGS 1649-1650*
}

\author{
JASON T. PEACEY \\ History of Parliament
}

\begin{abstract}
A B S T R A G T. After the execution of Charles I in I649 a series of daring and desperate attempts were made on the lives of agents and ambassadors dispatched to continental Europe by the fledgling republic. This essay explores the evidence relating to these plots, and to the murders of Isaac Dorislaus and Anthony Ascham, in an attempt to show that the royalists responsible were not merely desperadoes seeking revenge for the murder of their king, but the employees and emissaries of prominent exiled courtiers. The complicity of Montrose, Cottington and Hyde in such conspiracy can be both documented and explained, in the context of the struggle for diplomatic recognition and financial assistance in the months of shock, outrage and uncertainty after the regicide. The concerns of diplomacy and high politics which lay behind these plots also helped to determine the reaction of European leaders, as it gradually became clear on whose side fortune smiled in Britain.
\end{abstract}

We are firmly resolved by the assistance of almighty God, to be severe avengers of the innocent blood of our dear father, and by all ways possible to pursue and bring to their due punishment those bloody rebells who were either actors or contrivers of that barbarous and inhumane murder ... to chace, pursue, kill, and destroy as traytors and rebells, and cheefly those bloody traitors who had any hand in our deare father's murther.

These were the words, not of a rogue royalist, but of Charles II, early in I649. Such language of revenge, which filled his military commissions into the midI65os, seems directly responsible for the reign of terror instigated by exiled royalists upon representatives of the Rump posted to Europe during i $649-50 .{ }^{1}$ The assassinations plotted and undertaken in the immediate aftermath of the regicide were the forerunners of later attempts on both Cromwell and the regicides. ${ }^{2}$ If revenge was the ostensible motivation for such thuggery, then more Machiavellian motives concerned the need to enlist financial and military support for the abortive attempt to reclaim the Stuart throne in I65o, and the necessity of counteracting Cromwell's diplomatic efforts. Since the early i 640 os parliament had dispatched diplomatic representatives to the courts

* I would like to thank Emma Reiss for assistance with Spanish translations.

1 B.L. Add I 5856 , fos. 22-22v, 26, 26v, 30, $3 \mathrm{I}$.

2 A. Marshall, Intelligence and espionage in the reign of Charles II, I660-I685 (Cambridge, I994), pp. 279-300. 
of European leaders, and had placed its agents within the merchant communities. These agents represented a threat to Charles's fund-raising, and it was, therefore, necessary to remove them at all costs. Given that this drama unfolded on the continental stage, the final act depended, in the tense months after the execution of Charles I, upon the attitudes towards the protagonists on the part of European statesmen. ${ }^{3}$

Once it is established that assassination was a policy rooted in politics as well as emotion, decisions as to who gave the orders become essential. Sir Edward Hyde, earl of Clarendon, later told Sir George Downing that he doubted whether Charles II would ever give a direct order to carry out murders, but in the climate of shock and outrage which characterized the first months of the commonwealth, statements like those at the head of this piece may have been interpreted as signs of tacit approval and incited his followers to take matters into their own hands. If the disorder did not come directly from the commands of Charles himself, then it almost certainly came from the orders of those men to whom he entrusted 'public relations' with European leaders. ${ }^{4}$ This essay explores the phenomenon of royalist thugs and parliamentary agents in Europe, r649-50.

\section{I}

In the light of Charles's threats to hunt out the 'voters and actors' of his father's execution, the choice of parliamentary agents was unfortunate, to say the least. Henry Parker was one of the most reviled parliamentary propagandists, while Anthony Ascham was known to have supported the execution in print, and alleged to have assisted with the charge against the king. Richard Bradshaw probably suffered for his name and more famous kin. The first victim, however, was Dr Isaac Dorislaus, the judge advocate of the army under the earl of Essex, who had helped draw up the charge against Charles. ${ }^{5}$ Dorislaus' republican credentials stretched back to his history lectures at Cambridge in 1627 , instigated by Fulke Greville, Lord Brooke, ${ }^{6}$ from whose

\footnotetext{
${ }^{3}$ M. Guizot, History of Oliver Cromwell and the English commonwealth (2 vols., London, I854), I, I 98-302, 36 I-493, remains a useful introduction to the diplomacy of the period.

${ }^{4}$ Marshall, Intelligence and espionage, pp. 283-4.

${ }^{5}$ E. Peacock (ed.), Army lists (London, I874); B.L. Add 29974, fo. 369; W. C. Abbott, The writings and speeches of Oliver Cromwell (4 vols., Oxford, I988), I, 729, 73 I ; Public Record Office (P.R.O.), SP 28/252i, fo. 59v; Commons Fournals (CF), III, 376, 543, 722; Calendar of state papers domestic (CSPD) I644, pp. 261, 28I, 368, 377, 386-7, 400-1; CSPD 1644-5, pp. 70, 105; Historical Manuscripts Commission (HMC), Thirteenth report, appendix I (London, I89I), p. I 79. Dorislaus' influence has been detected in the wording of the charge. The only reason for his not having spoken at the trial was Charles's refusal to recognize the jurisdiction of the court, and his refusal to answer the charge: P. A. Maccioni and M. Mostert, 'Isaac Dorislaus (I 595-I649): The career of a Dutch scholar in England', Transactions of the Cambridge Bibliographic Society, viII (I 984), 435-7.

${ }^{6}$ Maccioni and Mostert, 'Dorislaus', pp. 4I 9-33; R. A. Rebholz, The life of Fulke Greville, first Lord Brooke (Oxford, I97 I), pp. 293-302; M. H. Curtis, 'The alienated intellectuals of early Stuart England', Past \& Present, xxIII (I 962), 25-43; Cambridge University Library (C.U.L.) Mm. I.47, pp. I 43-52; P.R.O. SP I6/86.87; SP I6/540.20; Bodleian Library (Bodl.) MS Tanner 7I, fos. 3-4, I 9-20, 24-5, I 88; Bodl. MS Tanner 72, fos. 233-4, 248-5I, 257-8, 284-5, 304; B.L. Add 2996o, fo. го; B.L. Add 5873, fo. I I Iv; H.M.C., Twelfth report, appendix I (London, I 888), pp. 370, 377-8.
} 
heir he was still receiving a pension in $\mathrm{I} 642 .^{7}$ In $\mathrm{I} 648$, Dorislaus was sent on official business to the United Provinces, but was refused an audience $;^{8}$ the Hague, to which he returned in April i649, with a scheme for peace and reciprocal alliance, was a hornet's nest of outraged royalist exiles, who noted his arrival, and fully understood his role in drawing up the charge that led to their monarch's death. ${ }^{9}$

One of the most important characters in our narrative is James Graham, marquis of Montrose. As Dorislaus arrived at the Hague, Montrose received a royal commission to negotiate with European dignitaries in Charles II's name; 'the whole of Northern Europe was to be scoured for men and money'. Montrose was, as Maclean states, 'the only leading royalist who came to terms with the exiled king's poverty, or had enough skill to raise men, arms, food, ships, and above all money, for an expedition of any sort ${ }^{10}$ This awareness, and his own royalist zeal, proved a potent combination. One of those who knew him claimed that, upon hearing of the regicide, 'his grief became passion, his anger was heightened to fury, and his noble spirit was so overwhelmed that his limbs stiffened, and he fainted in the midst of his attendants, falling down like one dead'. However, 'the sweeter thought of the vengeance he so ardently longed for recalled new life into his choking heart', ${ }^{11}$ and he is supposed to have written of Charles I, with the point of his sword, that 'I'll sing thy obsequies with trumpet sounds, and write thy epitaph with blood and wounds'. He certainly told Hyde that, 'if affection and love to the justice and virtue of that cause be not incitements great enough, anger and so just revenge, methinks, should wing us on ${ }^{12}{ }^{12}$ Appropriately, his personal motto was Nil Medium. ${ }^{13}$ To this determination and resentment we should add the words of the widowed queen, Henrietta Maria, who wrote to him in March i649:

le meutre comis en sa personne doit augmenter a tout ses serviteurs la passion de chercher tout les moyens de ses revancher d'une mort sy abominable, - et comme je ne

7 Warwickshire Record Office, GR I 886.

${ }^{8}$ C. H. Firth (ed.), Clarke papers (4 vols., Camden Society, I 894), II, $4 \mathrm{I}^{-2}$; Perfect Occurrences, no. 67 (7-14 Apr. I648), p. 482; Perfect Diurnall, no. 246 ( I -1 7 Apr. I648), p. I 983 ; Perfect Occurrences, no. 77 (I6-23 June I648), p. 562; Mercurius Pragmaticus, no. I5 (4-I I July I648); P.R.O. SP 46/ I 16/259. For the background to Anglo-Dutch affairs during the revolutionary period, see: S. Groenveld, 'The English Civil Wars as a cause of the first Anglo-Dutch war, I640-I652', Historical Fournal, $\mathrm{xxx}$ (1987), 54 I-66.

${ }^{9}$ O. Ogle and W. H. Bliss (eds.), Calendar of the Clarendon state papers, I (Oxford, I872), 428; Calendar of State Papers Venetian (CSPV), I647-52, p. 66; CSPD I649-50, pp. I 4, 47, 97, 99, I oo, 103-5; Dictionary of National Biography $(D \mathcal{N B})$; W. D. Macray (ed.), Calendar of the Clarendon state papers, II (Oxford, I 869), Io; Groenveld, 'English Civil Wars', pp. 553-4.

${ }^{10}$ E. J. Cowan, Montrose for covenant and king (London, I 977), pp. 266, 270-2; J. N. M. Maclean, 'Montrose's preparations for the invasion of Scotland, and royalist missions to Sweden, I649- I $_{5} \mathrm{I}$ ', in R. Hatton and M. S. Anderson (eds.), Studies in diplomatic history (London, I970), p. 7.

${ }^{11}$ G. Wishart, The memoirs of Fames, marquis of Montrose (London, I 893), pp. 228-9.

${ }^{12}$ Wishart, Montrose, pp. 505-6; Memorials of Montrose and his times (2 vols., Edinburgh, I $848-50)$, II, 369 .

${ }^{13}$ Sir J. Balfour, The historical works (4 vols., London, I825), III, 439-40; S. R. Gardiner (ed.), Letters and papers illustrating the relations between Charles II and Scotland in I65o (Edinburgh, I894), pp. $5^{-6 .}$ 
doubte point que vous ne soyes bein ayse de en avoir les occations, et que pour sesta effect vous ne faises tout ce qui despandra de vous, je vous conjure, donc, le vouloir vous joindre avec tout seux votre nation qui voudroit resentir comes ils doivant settre mort. ${ }^{14}$

Sir Edward Nicholas was more blunt: 'I marvel that none of the Ranters about Pr. Charles do cut the throats of Strickland and Dorislaus, the Parliaments [agents] in Holland.' 15

After an unsuccessful attempt on his life on I May, Dorislaus' enemies finally caught up with him at ro o'clock the following evening, at the Witte Zwaan Inn. His servants related the event, perhaps hagiographically, as follows:

twelve men came to the door, all armed, head, back, breast and thighs; six whereof came along an entry leading to Dr Dorislaus his chamber, which the woman of the house perceived, and thereupon cried out 'murther'. Whereupon the informants (then attending the Doctor at supper) stept to the door, shut it, and held it, until the doctor (who had notice before of a private door) looked for it, but not finding it, he returned to his chair, and folding his arms, lent upon it, with his face toward the door. The murderers rushed in upon your informants, they were not able to make any resistance, but received sore wounds, and (with swords and pistols set to their breasts) were enforced to stand still, while the rest, running up to the doctor, run him through; he no whit altering his posture, until the time he fell.

The murderers fled proclaiming: 'Thus dies one of the king's judges. ${ }^{16}$ Dorislaus, who suffered a fractured skull, and a punctured heart and liver, was little mourned by his fellow countrymen, judging from the hostile literature which emerged in the following days. ${ }^{17}$

The murder was committed by a group of Scotsmen in the service of Montrose, including Colonel Walter Whitford and Sir John Spottiswood. ${ }^{18}$ Whitford, the son of the ejected bishop of Brechin, had sought confessional advice about his plan to murder Dorislaus from an English priest named Robinson, confessor to the Portuguese ambassador. The ambassador was himself privy to the plot, and sheltered Whitford after it was enacted. After escaping to Brussels, Whitford was captured by the Scots the following year, but received a last-minute reprieve upon admitting his role in the murder, which 'counted to him for righteousness'. He resurfaced to scare ambassador Downing at the Hague in I 658, and was awarded a pension by both Charles II and James II. ${ }^{19}$ Like Whitford, Spottiswood came from an eminent family of

14 Memorials of Montrose, II, 372.

15 H. Cary (ed.), Memorials of the great Civil War (2 vols., London, I842), II, I 04-7; B.L. Add 4 I8o, fo. 7v; G. F. Warner (ed.), The Nicholas papers (4 vols., Camden Society, i 886), I, I 35.

16 F. Peck, Desiderata curiosa (2 vols., London, I 779), II, 422-3; H.M.C., Thirteenth report, appendix I, p. 5I3; Maccioni and Mostert, 'Dorislaus', pp. 439-40; B. Whitelocke, Memorials of the English affairs (4 vols., Oxford, I 853), III, 30. ${ }^{17}$ Maccioni and Mostert, 'Dorislaus', pp. 462-70.

18 Peck, Desiderata, II, 423; Edward Hyde, earl of Clarendon, The history of the great rebellion and Civil Wars in England (ed. W. D. Macray, 6 vols., Oxford, I888), v, 24; Notes and Queries, $4^{\text {th series, }}$ III (I 869), 49 I-2.

19 E. Scott, The king in exile (London, I905), pp. 96-7; C.U.L., Mm.r.46, p. I4I ; H.M.C., Thirteenth report, appendix I, p. 59 I T. Carte (ed.), A collection of original letters and papers concerning the affairs of England (2 vols., Dublin, I 759), I, 292-3; Mercurius Politicus, no. 3 (20-27 June I65o), p. 34; Clarendon, History, v, I 2 I ; $D \mathcal{N B}$ (see David Whitford, Walter Whitford and Walter Whitford 
clerics, bishops and courtiers, and both he and his brother were colleagues of Montrose. Unlike Whitford, however, he would not escape execution after the failed Scottish invasion. ${ }^{20}$ Of the other murderers we can be less certain. Walter Breame, a Kentish cavalier, was arrested arriving from Holland in June I649, and sent to the Tower for possessing letters referring to the murder, and for inconsistencies in his own account. Ferdinand Storey, 'a delinquent Papist', formerly part of the Oxford garrison, was sent to the Gatehouse the following February on similar suspicions; Captain Francis Murfield was sought out for words supporting the murder, and then imprisoned as a suspected accessory; and one Captain Norwood was ordered to pay a bond of $£, 500$ for six months to the sheriff of Kent for his part in the plot. ${ }^{21}$ Even Lord Hopton was suspected. ${ }^{22}$

Walter Strickland had the unenviable task of treating with the Dutch in the aftermath of the murder, and of living amongst those hostile to him. Nevertheless, he was more astute than either Dorislaus or Ascham, and more level-headed than Bradshaw. He had evidently urged Dorislaus to move to his own residence rather than stay at the inn, and despite narrowly avoiding death himself, having left Dorislaus only an hour before the murder, Strickland commented calmly that 'I must be next'. ${ }^{23}$ Once news of the murder reached London, the Dutch were requested to protect Strickland, and to return Dorislaus' body, which lay in state before a full state funeral in Westminster Abbey, a stage managed piece of propaganda on which the government was prepared to spend $£ 25 \mathrm{O}^{24}$

Joachimi, the Dutch representative in England, testified his affection to the regime, and his care for the future security of English agents, but a more

jr); Whitelocke, Memorials, III, 205; T. Birch (ed.), A collection of the state papers of Fohn Thurloe (7 vols., London, I 742, hereafter Thurloe SP), v, 3 I 5 ; VII, 429 ; P. R. Newman, Royalist officers in England and Wales, I $_{42-1660}$ (London, I98I), p. 408.

${ }^{20}$ DNB; Balfour, Historical works, III, 35, I 52, I 58 ; Cowan, Montrose, p. 283; M. Napier, Memoirs of Montrose (2 vols., Edinburgh, I 856), II, 779; Memorials of Montrose, II, I 22, I 24, I 37, 233, 253, 254 ; Mercurius Politicus, no. I (6-I3 June I650), pp. 7, I5; B.L. Egerton 2542, fo. 45; Whitelocke, Memorials, III, 20I.

${ }^{21}$ A. M. Everitt, The community of Kent and the great rebellion, I640-I660 (Leicester, I966), p. $28 \mathrm{I}$; CSPD I649-50, pp. I 33, I55; 1650 , pp. I 26,$525 ; 165^{I-2}$, pp. 250, 555, 556. The Venetian ambassador reported, in June i649, that five suspects were apprehended on a ship from Holland, and imprisoned in Pendennis Castle; CSPV $1647^{-52}$, p. го7.

${ }^{22}$ Whitelocke, Memorials, III, 34 .

${ }^{23}$ Cary, Memorials, II, I3 I-3; Bodl. MS Tanner 56, fos. 38-38v.

24 J. Milton, Complete prose works (8 vols., New Haven, I 953-82), v, 488; CSPD I649-50, pp. I 3 I, I33, I35, I37, I39, I4 I, I43, I53, I59, I64-5, I7 I, I8 I, I83, 300, 31 3, 432 ; C.U.L. Mm.I.46, p. I6I ; Notes and Queries, 4 th series, III (I869), 367-8. For the funeral see: M. J. Seymour, 'Progovernment propaganda in interregnum England, I649-I660' (unpublished Cambridge University $\mathrm{PhD}$ thesis, I 986), pp. 208-1 I ; Maccioni and Mostert, 'Dorislaus', pp. 442-3; P.R.O. SP 25/62/275, 363, 37 I, 629, 432; SP 46/95/ I $30 ; A$ salt teare (London, I649), Thomason Tracts, 669 f. I4 (43). Dorislaus' children received pensions and employment: P.R.O. E 404/236 (unfol.); E 404/237 (unfol.); SC6/Chas.I/r667 m.I4d; SC6/Chas.I/I668 n.ıo; SC6/Chas. I/ı669 m. Iod; SC6/Chas. I/ 1670 m. I2d; B.L. Add 4197, fo. го7. 
representative response was that of Sir Edward Nicholas, who told the marquis of Ormonde of 'the most deserved execution of that bloody villain Dorislaus'. ${ }^{25}$ The Venetian ambassador at Munster gave the most pertinent account of the affair when he informed the doge of the "well merited punishment of his temerity, as he was one of the officials who demanded and contrived the death of the late king Charles, and he had the audacity to betake himself to Holland where the king's son was'. ${ }^{26}$ Perhaps feeling that Strickland would be intimidated by the death of his colleague, the royalists stepped up their attempts to gain assistance, in the form of $£ 20,000$, from the Dutch. Intimidation, however, as the royalists were to discover throughout Europe, did not always produce the desired results. While Sir William Boswell worked to ensure that Strickland could gain no audience, the reluctance of the States General to see him caused tension between themselves and the individual states, who gave Strickland protection, and placed a bounty of I, ooo guilders on the murderers. ${ }^{27}$ Strickland felt more secure after the departure of Montrose, and although he was aware of continued animosity in some quarters, and of a plot to send him the way of Dorislaus, he realized that this could work in his favour, since 'thire hatred makes more friendes of those, who have the power to doe us good'. He reported progress in enforcing the Engagement, while Boswell could only watch frustrated as Strickland managed to secure help in his attempt to block the circulation of Salmasius' Defensio regia.$^{28}$ Ironically, the successful elimination of Dorislaus had the effect of hastening the departure of Charles II from the Hague. ${ }^{29}$

Despite such progress, the council of state made another careless move in their plans for the embassy to the Hague in the following year. Relations had improved with the death, in November i65o, of William of Orange, Charles II's strongest ally on the continent, but the decision to allow Dorislaus' son to accompany Strickland and Oliver St John seems particularly foolish, given that they intended to raise the issue of the murder ${ }^{30}$ Unsurprisingly, their arrival brought another attempted murder, plotted by a 'desperate cavalier' connected to the queen of Bohemia. Using the ploy of warning St John of dangers to his safety, James Apsley secured a late-night audience, but was frustrated by the suspicions of St John's son. Having planned to strangle the ambassador with a rope coiled round his wrist, Apsley told a rambling story of the alleged plot, before eventually leaving. He tried to make the best of a failed mission with an attempt on the life of one of St John's servants who accompanied him, only to be foiled when the servant slipped off his wig to

\footnotetext{
${ }^{25}$ CSPD ${ }_{1} 649-50$, pp. I44-6; D. Nicholas, Mr Secretary Nicholas (London, I955), p. 237; Carte, Original letters, II, $29 \mathrm{I}-2$.

27 Macray, Calendar, II, I4; B.L. Add I5856, fo. I9v; Thurloe SP, I, I I 2-I6, I 23-5, I 29; Maccioni and Mostert, 'Dorislaus', p. 440.

28 Thurloe SP, I, I 1 7-20; Cary, Memorials, II, 203-10; Bodl, MS Tanner 56, fos. I57-58v; B.L. Add 37047 , fo. 36 .

${ }^{29}$ H.M.C., Report on the manuscripts of the marquis of Ormonde, II (London, I 899), 93.

${ }^{30} \operatorname{CSPD}{ }_{1} 6_{5 I}$, pp. 57-8; H.M.C., Thirteenth report, appendix I, pp. 558, 563 ; Peck, Desiderata, II, 429; Thurloe SP, I, I 74; P.R.O. SP 46/96/ 197.
} 
evade the would-be assassin! When the hapless Apsley was eventually captured, he admitted to having been encouraged by his employers. ${ }^{31}$

Although royalist tactics in the United Provinces backfired, the Dorislaus affair lived on in contemporary political consciousness. John Lilburne expressed his fears of being 'Dorislaused', while one Bradshaw boasted of wearing the dagger responsible for the murder. More importantly, the matter became part of the catalogue of complaints against the Dutch employed during the wars between the two republics. ${ }^{32}$

I I

The employment of envoys and agents was by no means a development of the Civil Wars, but aside from Walter Strickland, parliament only developed anything approaching a coherent network of agents in early i648, when

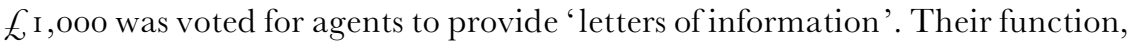
less diplomatic than intelligence gathering, meant that those best placed to undertake such work were men like Henry Parker, secretary to the Merchant Adventurers at Hamburg. Parker, parliament's most important political pamphleteer of the i64os, had left England in late i646, having fallen foul of the factional wrangling within Westminster. He was ideal for the new role, since what was required was not merely intelligence from politically astute men like himself, but polished prose for parliament's newspapers. Parliament had, by the late i64os, developed a network of both intelligencers and news writers, who were brought together by men in Westminster like John Thurloe. ${ }^{33}$ Parker's name was singled out in the Commons' resolution of January I648, and Strickland was requested to 'take order with Mr Parker at Hamburg ... to give us from time to time constant advertisements of what that king [of Denmark] treats or does'. ${ }^{34}$ In early i 649 the council of state told Parker of their 'being very glad you are where, by reason of your employment for the company, you have an opportunity of informing yourself, without suspicion, of what is in design, to the prejudice of this commonwealth'.$^{35}$ Parker's presence, known to the royalists, would have been annoying not simply because of the intelligence-gathering implications. His position with the Merchant Adventurers meant the existence of a rebel voice within a community whose support

${ }^{31}$ Perfect Diurnall, no. 7 I (I 4-2 I Apr. I65 I), pp. 965-6, 975-6; no. 72 (2 I-28 Apr. I65 I), p. 985 ; and no. 74 (5-I2 May i65I), p. Io 5 5; Cary, Memorials, II, 259-63. An abortive attempt was made to capture Theodore Jennings, messenger of the council of state: Perfect Diurnall, no. 75 ( I 2-I 9 May i65I), p. I029. There is a legend, possibly apocryphal, that Oliver St John met the duke of York in a park, and when he would not give way, the prince threw at him his hat and said 'learn, parricide, to respect the brother of your king'. St John is supposed to have replied, 'I scorn to acknowledge either you or him of whom you speak, but as a race of vagabonds'. Having drawn their swords the two were only prevented from fighting by their respective companions: Guizot, History, I, 255 .

${ }^{32}$ P. Gregg, Free-born Fohn (London, 1986), p. 312; CSPD 1656-7, p. 109; Dr Dorislaw's Ghost (London, I652), Thomason Tracts, 669 f.i6 6 (5I).

${ }^{33} \mathrm{CF} \mathrm{v}, 427$. Parker's career and the themes of this passage are explored in my Cambridge University PhD thesis: 'Henry Parker and parliamentary propaganda during the English Civil Wars' (r 994). $\quad{ }^{34}$ Macray, Calendar, II, I94. $\quad{ }_{35}$ CSPD I649-50, pp. 34-5. 
and financial assistance was valuable to both sides. The prince of Wales demanded $f 5^{\circ}$,ooo from the merchants at Rotterdam in July i 648 , and the duke of York later requested $\mathcal{E}_{\mathrm{I}}, \mathrm{ooo}$ a month from the merchant community. Little wonder, then, that Charles II instructed Stephen Goffe to prevent the reception of rebel envoys. ${ }^{36}$

Another royalist trouble-shooter in Europe at this time was Sir John Cochrane, a regimental commander at Edinburgh in I640, who had been arrested the following year for his part in the plot against the parliamentarian leadership. Cochrane donated his services to the king at York in I 642, and after a brief spell in command of Towcester in $\mathrm{I} 643$, was sent on a mission to Denmark, and entered into negotiations with the duke of Courland in Poland. ${ }^{37}$ In late 1648 he was with the prince of Wales in the Low Countries, from where he was despatched once more to Courland, and to Denmark, from the last of which he secured pledges of help. ${ }^{38}$ By February 1649 he had arrived at Hamburg. ${ }^{39}$ As well as issuing appeals to other European rulers, which did not elicit an immediate response, attempts were made to tap the resources of the merchant community. ${ }^{40}$ London attempted to ensure that the Hamburg traders remained 'politically correct' in their membership, telling the company that

we think that those employed on merchants' affairs, as ambassadors, counsels, \&c, should be persons of approved fidelity and sufficiency, and well affected to the present government. We therefore wish you not to dispatch any such persons without first presenting their names to us and receiving our express approbation.

It was at precisely this time that Parker's surviving letter of intelligence arrived in London, detailing the activities of the Scots in Europe, and the threatening movements of the Swedes and the Danes resulting from royalist negotiations. ${ }^{41}$ It was in the light of Parker's intelligence that Cochrane endeavoured to cajole, and eventually cudgel, the merchants into turning away from parliament.

As early as August i 648, Thomas Skinner (secretary to the English Merchant Adventurers) petitioned parliament regarding the interception of merchants' ships by royalist gangs, and this sense of disorder and desperation is nowhere

${ }^{36}$ H.M.C., Report on the Pepys manuscripts (London, I9 I I), pp. 2 I 5-16, 2 I 8, 2 I 9, 22 I-2, 224-5, 259, 27 I, 283; DNB ; Ogle and Bliss, I, Calendar, 428-3o, 435-6, 448-9; Warner, Nicholas papers, I, 93, 97 .

37 DNB; D. Laing (ed.), The letters and journals of Robert Baillie (3 vols., Edinburgh, I 84 I), I, I9 I, 260, 383, 392; II, 9, 31 о Balfour, Historical works, III, 63, Iо г, I 03, г 23-5; H.M.C., Fourth report (Nendeln, I979), pp. I63-70; C. V. Wedgwood, The king's peace (London, i 966), pp. 4I 7-24; Warner, Nicholas papers, I, 56; Memorials of Montrose, I, 302-6; H. F. Morland-Simpson, 'Civil War papers i643-I650', in Miscellany of the Scottish History Society, I ( 1893), I 54-66; Ogle and Bliss, Calendar, I, 320-52; Mercurius Britanicus, no. 97 (8-I 5 Sept. I645), pp. 866-70.

38 Morland-Simpson, 'Civil War papers', pp. i67-8; H.M.C., Pepys, pp. 230, 284; Carte, Original letters, I, 232 ; B.L. Add 705 I 8, fos. I 59, I6 I-2.

39 Morland-Simpson, 'Civil War papers', p. i69. $\quad 40$ B.L. Add 705I8, fos. I66-76.

41 Henry Parker to Lenthall, 23 Feb. i649, Gentleman's Magazine, xxxv (Mar. I 765). Parker's letter seems to have been read in parliament on I5 March, when money was ordered to be despatched to him: Perfect Diurnall, no. 294, p. 2377. The council later asked Parker to obtain information regarding military preparations in Sweden and Denmark: CSPD I649-50, p. I85. 
better portrayed than through the events in Hamburg during I $649 .{ }^{42}$ Initially, the aim of Cochrane was to intimidate the merchant community. Parker's letter to Lenthall recounted that 'The king's death is strangely taken here by all sorts of people; we can scarce walk in the streets. 'Tis scarce credible how bitterly the vulgar and better sorts of people do resent it, though few of them hold him less than a tyrant.' Moreover, he reported that Cochrane, 'terrified our deputy and minister', an incident fleshed out in an official newspaper:

The rage is such here against the English that the servants of Col. Cochrane laid wait for the English minister, when he was going to the English house to preach, and would have pistolled him; [but] the pistolls not taking fire, the fellows being mad with anger drew their poyniards to stab the minister, who crying out murther, was rescued by the citizens. $^{43}$

Predictably, such lawlessness elicited from London letters on behalf of the Hamburg merchants. ${ }^{44}$

Charles II, meanwhile, ordered Cochrane to 'most efficiently labour with them not to admit or acknowledge any person that shall be employed to them by the rebels in England', and Cochrane responded with an audacious plot to abduct leading merchants, aimed at raising a ransom as much as cleansing their membership. ${ }^{45} \mathrm{He}$ clearly believed that he had widespread support in Hamburg, and that he 'would find few to cross any design' against the merchants, 'but many well wishers'. He went so far as to say that 'nous sommes ici dans un nouveau monde', and justified his plans on the grounds that 'the rebels had been using all ways imaginable to hinder me from public audience, and indeed they had reason, for they knew that they would be able in process of time by bribery and threatening, to effectuate with the senate what they pleased ${ }^{46}$ Cochrane later claimed that the merchants obstructed his attempts to negotiate with them by sending 'the meanest of their trivial servants'. In response, he wrote to the merchants, 'to try if any hopes were left to prevail by fair means'. Whether or not this frustration was justified, Cochrane's language was clearly intended to intimidate. He railed against those 'seditious' merchants bound to 'rebellious courses', and claimed that he had been 'desirous rather to establish a fair correspondence with you than to act with rigour against you, as I now must... I am constrained to change my tune, and must endeavour to press with rigour, what I could not obtain by fair means'.

${ }^{42}$ H.M.C., Pepys, p. 273; W. E. Lingelbach, 'The Merchant Adventurers at Hamburg', American Historical Review, Ix (1903-4), 265-87. Most of the original records of the merchants were lost in Hamburg's great fire of 1848 .

${ }^{43}$ Gentleman's Magazine, xxxv (1765), 35; Perfect Diurnall, no. 296, p. 2352; Perfect Diurnall, no. 297, p. 24I5. The minister had apparently been vociferous in his sermons against the royalists: H. Hitzigrath, Die kompagnie der Merchant Adventurers und die Englische kirckengemeinde in Hamburg I6II-I835 (Hamburg, I904), pp. I $5^{-16 .}$

${ }^{44}$ CSPD I649-5o, pp. 48, 52, 62; CJ vi, I 76; Milton, Complete prose works, v, 482.

${ }^{45}$ H.M.C., Thirteenth report, appendix II (London, I893), pp. 26-7; Maclean, 'Montrose's preparations', p. ıо; Wishart, Montrose, p. 258; B.L. Add 70518, fos. 163-63v.

${ }_{46}$ 'Sir John Cochrane's relation of the particulars that have occurred in his negotiations since his coming to Hamburg', in Morland-Simpson, 'Civil War papers', pp. I 75-7; Cowan, Montrose for covenant and king, p. 272. 
He concluded that the merchants should not doubt his ability to act upon such threats. ${ }^{47}$ Meetings between Cochrane and the merchants ensued, but the former remained unsatisfied by what he saw as the merchants' lack of respect. ${ }^{48}$ Having failed to enlist the support of the Hamburg senate with his claims that the merchants had imprisoned royalists, and issued propaganda calling for the execution of the king, Cochrane finally carried out his threat of force. ${ }^{49}$

Having obtained a ship, Cochrane's men weighed anchor in Pinneberg, with the consent of the Danish authorities. ${ }^{50}$ Since he lacked the trust of the merchants, Cochrane seduced them from their safe-houses by means of a forged letter from Sir William Strickland, introducing Edward Harrington, ironically as one who would help them deal with the threat of force from Cochrane and Montrose. ${ }^{51}$ Harrington would later claim that he had been acting directly upon the orders of Charles II. ${ }^{52}$ It appears that Walter Strickland had sent a letter to Hamburg telling them of Harrington, expecting Parker to be there, and presuming him able to deal with it effectively. Parker had returned to England, however, and the less politically astute merchants who remained fell for Harrington's ruse. ${ }^{53}$ What happened next is best related by a contemporary newspaper report:

[Harrington] told them he was acquainted with Cochrane and knew his design, and was an intimate friend of the Parliament's agent Mr Strickland. Having thus got credit with Mr Crisp, he one morning came to him and told him that Mr Strickland was arrived in this town, had business to the King of Denmark for facilitating whereof he desired to speak with the English merchants, but would have things kept secret, and that he desired Mr Crisp to come to him to such a place, who took his coach, coming to the appointed place, some musketeers fell upon him, bound his hands and feet, hailed him to a ship, being there by threat he was forced to write to the merchants' deputies Master Lee and Mr Palmer, to come to Mr Strickland, who credited Master Crispe's letter came also, who were faired as the first, and all these three carried away. ${ }^{54}$

The aim was to ransom the merchants for $£ 30,000$, but the villains, 'being too much puffed up with their former success, and an opinion that no creature living would assist the rebels to pursue after them', delayed before removing from the scene of their crime, allowing time enough for the merchants to enlist 200 musketeers to effect a dramatic rescue. ${ }^{55}$

Parliament responded with sharp letters to the Hamburg authorities, demanding justice, and action against Cochrane. They ordered naval protection for merchant ships, and enforcement of the engagement, and

47 'Cochrane's relation', pp. I 79-80; P.R.O. SP 82/7/ i 26.

48 'Cochrane's relation', p. I80. $\quad{ }^{49}$ Ibid. pp. I8I-3. $\quad 50$ Ibid.

51 Sir William Strickland to Harrington: P.R.O. SP 82/7/ 1 29-3o; Bodl. MS Tanner 56, fo. 68; Cary, Memorials, II, I 48-50. 52 P.R.O. SP $82 / 7 /$ I 7 I.

${ }^{53}$ Bodl. MS Tanner 56, fos. 82-3; Cary, Memorials, II, I 55-9. Parker quit his post in the spring of I649, despite being re-elected to his secretaryship, to return to England, and become registrar of the prerogative court of Canterbury, and secretary to Cromwell's Irish campaign: P.R.O. SP 46/95/ I 53-4; Peacey, 'Henry Parker', ch. 3 .

54 Perfect Diurnall, no. 3 I 5 (6-I 3 Aug. I649), p. 2683. The story appeared, in almost exactly the same format, in other newspapers: Kingdomes Faithful and Impartial Scout, no. 28 (3-1o Aug. I649), p. 22 I ; Moderate Messenger, no. I6 (6-i 3 Aug. i649), p. Iо7.

55 P.R.O. SP 82/7/ I 27; 'Cochrane's relation', pp. i8 I-3; Perfect Diurnall, no. 3 I5, p. 2683. 
attempted to provide an effective replacement for Parker as official agent in Hamburg. The council expressed their opinion that the merchants had shown more than a little 'credulity' in succumbing to this plot, and obviously felt that Parker, or someone like him, would have been able to prevent 'encouragement to those plagiaries to continue that trade of taking and ransoming men' ${ }^{56}$ They initially appointed Anthony Ascham to the Hamburg post, but his ill-health forced them to turn to Richard Bradshaw. ${ }^{57}$ Cochrane, meanwhile, responded to the imprisonment of the surviving conspirators with an official complaint to the senate, a move which astonished the merchants and council of state. ${ }^{58}$ Other royalists were not so unrepentant as Cochrane, however. Montrose travelled to Hamburg to reduce tension, perhaps sensing that things were beginning to turn against the cause of Charles II. Not only were the merchants rejecting their overtures, but Cochrane had miscalculated the mood of the people of Hamburg. Cochrane suspected that agreement had been struck between the rebels and the city, and complained that the merchants were treated as 'their Burgers'. 59

In instructing Montrose to repair to Hamburg, Charles noted, 'how unnecessary it is for us at this time to make new enemies, or to be over severe in our resentments of such things as in a time of more prosperity we ought to insist upon'. Montrose was ordered to 'compose the differences, and settle a better understanding between us and the said town of Hamburg', although this was evidently only regarded as the best way to secure financial loans. While Charles insisted that, "in that particular of their resolution to receive public minister from the bloody rebels in England, we cannot but believe it to be inconsistent with all amity and alliance with us', nevertheless Montrose was to proceed 'without any menaces of threats'. ${ }^{60}$ Whether Montrose succeeded in any of these aims is unclear, but both he and Cochrane seem quickly to have moved on to pastures new, in search of easier pickings. ${ }^{61}$ Cochrane still sought to obtain money, 'partly with threats, partly with fair words', as he told

\footnotetext{
${ }^{56}$ CSPD I649-50, pp. 22 I-2, 258, 26 I, 265, 269-70, 270-I, 496; P.R.O. SP 82/7/г 27, I $39 ; C \mathcal{f}$ vI, 274; J. Milton, Letters of state (London, I694), pp. I-6; Milton, Complete prose works, v, 489-93; H.M.C., Sixth report (Nendeln, I979), p. 427. The council evidently wanted Lee to take over the job, but his excuse that politics involved 'matters wherein I have never been versed', taken upon the advice of Parker, who was 'far better versed in all state affairs than myself', seems justified in the light of these events: CSPD I649-50, pp. гоo-I; P.R.O. SP 82/7/ г 27, I42. Disaster almost struck again in the form of the planned appointment of William Northey, a barrister educated at Oxford, Leyden and the Middle Temple; but he was recognized as being 'not well affected to our state': J. Foster, Alumni Oxonienses (4 vols., Oxford, I892), III, I078; Register of admissions to the honourable society of the Middle Temple (3 vols., London, I 949), I, I 29; E. Peacock, English speaking students ... at Leyden (London, I883), p. 74; P.R.O. SP 46/95/I53v, I85-86v; SP 82/7/I 33, I 35-7; B.L. Add I I049, fos. I05-27 (letters of William Northey and his brother Thomas, I643-5).

57 P.R.O. SP 46/95/ I 85-86v; CSPD I649-50, pp. 288, 297, 496; Milton, Complete prose works, v, 5I4-I5. $\quad 58$ 'Cochrane's relation', pp. I8I-3, I84; P.R.O. SP 82/7/ I 27.

${ }_{59}$ Morland-Simpson, 'Civil War papers', p. i 74; Maclean, 'Montrose's preparations', pp. I 2-I3; 'Cochrane's relation', p. I84.

${ }^{60}$ Memorials of Montrose, II, 392-3; Wishart, Montrose, pp. 258, 26o, 507-8.

${ }^{61}$ Maclean, 'Montrose's preparations', p. I4; Morland-Simpson, 'Civil War papers', pp. г87-91. They left behind many influential Scotsmen in Hamburg: Wishart, Montrose, pp. 269-70; Sir J. Turner, Memoirs of his own life and times (Edinburgh, I829), p. 9I.
} 
Montrose, and we may conclude that it was not so much his violent methods that frustrated his peers, as his failure to carry them out successfully. ${ }^{62}$

That the exiled royalists did not reform their violent ways is apparent from the experience of Richard Bradshaw, Parker's replacement in Hamburg. ${ }^{63}$ Bradshaw, a kinsman of John Bradshaw (lord president of the council of state), was a Chester merchant who became sheriff, and later mayor, of the town. During the Civil War he acted as collector of contributions for the defence of the city, and quartermaster of the horse under Sir William Brereton. ${ }^{64}$ On departing for Europe, Bradshaw received a salary of $£ 800$ from the council of state, as well as $£ 600$ to transport himself and his family to Hamburg. ${ }^{65}$ Strickland had written to Lenthall, after the abduction of the merchants, that 'truly I know not, since this law of taking and killing men is grown thus common in foreign parts, how any man who serves you abroad, or owns the interest you are engaged in, can be made safe ${ }^{9}{ }^{66}$ This theme would be repeated for at least two years, and Strickland said that 'I am now the man they hate the most'. ${ }^{67}$ Bradshaw championed the cause of justice immediately upon his arrival, but found himself in danger from the very outset of his stay. ${ }^{68}$ Testimony was given as early as I May I650 against one captain Blincko, who had said, 'that if the agent whom he named Bradshaw, did come forth out of doors, he would lose his life, for that there were those ready that would do it' ${ }^{69}$ Bradshaw was exasperated to find that the malefactors, initially banished from the city, had managed to return by offering their services to the king of Spain. Bradshaw complained of their 'mock banishment', and claimed that Harring-

\footnotetext{
${ }^{62}$ Memorials of Montrose, II, 4 I 7 . There were claims that Cochrane absconded with the money he raised, but these were vigorously denied, and he and Montrose seem to have had great success: Morland-Simpson, 'Civil War papers', pp. I91-2, I93-2 I2; H.M.C., Pepys, p. 288; 'An account of Montrose's actions', in Carte, Original letters, I, 345-5 I, 358-9; B.L. Add I 2 I 86, fos. 6o-6ov; B.L. Add 37047 , fos. I 26 , I65, I73v; P.R.O. SP 84/I59/I9; H.M.C., Sixth report, p. 427; S. M. Ffarington (ed.), The Farington papers (Chetham Society, xxxix, i856), pp. I58-9. Neither Cochrane nor Montrose managed to obtain money from Oldenberg: L. Miller, Fohn Milton and the Oldenberg safeguard (New York, I985), pp. I9, 48, 5I ; M. Hastings, Montrose (London, I977), p. 327 ; R. Williams, Montrose, cavalier in mourning (London, I975), p. 336. Maclean claimed that 'it later came to light that Cochrane and Ogilvie were in league to defraud the royalists of money and supplies'; Maclean, 'Montrose's preparations', p. 27. Cochrane made some sort of peace with the Protectorate: CSPD I65I-2, pp. 152-3; CiSPD 1653-4, p. 273; CSPD I656-7, p. 82.

${ }^{63}$ Bradshaw was still in Chester on 2 March: The Cheshire Sheaf, I (May I878), pp. i 7-18.

${ }^{64}$ DNB; H.M.C., Eighth report (Nendeln, I979), p. 365; CSPD I649-5o, p. I 43; B.L. Stowe 8 I I, fo. 67 ; Farington papers, pp. 92, I 57 ; Bodl. MS Tanner 56 , fos. 80-80v; A. M. Johnson, 'Politics in Chester during the Civil Wars and the interregnum I640-I662', in P. Clark and P. Slack (eds.),

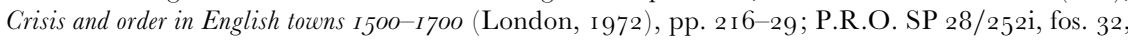
3I2v; SP 28/255 (unfol.).

${ }^{65}$ CSPD I649-5o, pp. 498, 598; ${ }_{1650}$, pp. 20-2 I, 40, 45, 67-9, 572; P.R.O. SP 2 I/29/1 $96 ; C f$ vi, 353; Milton, Letters, pp. 29-30. He wrote to lord president Bradshaw that his plans to take with him Charles Herle ('the ablest scholar in all these parts... He has a gallant pen, and able parts') were shelved because of the latter's connections to the earl of Derby: CSPD I649-50, p. 5 I 2.

${ }^{66}$ Bodl. MS Tanner 56 , fos. $82-3$.

${ }^{67}$ Thurloe SP, I, I I 7, I I9; Wishart, Memoirs, pp. 253-4.

${ }^{68}$ CSPD I649-5o, p. 330; P.R.O. SP 82/7/I 47; Milton, Letters, pp. 6-9; P.R.O. SP 82/7/I 5 I, I 58 .

${ }^{69}$ P.R.O. SP $82 / 7 / \mathrm{r} 69$.
} 
ton and Jones were visible in town and bent on revenge; that Cochrane's chaplain served as a focal point for disaffected royalists; and that Halterman, who had been responsible for the attack upon the minister in February i649, was also released. ${ }^{70}$ Bradshaw concluded that he was 'a prisoner', unable to move freely around town, and felt that the senate was partly to blame. ${ }^{71}$ While they pretended to be neutral, "their affections and real respects are only and altogether bent to the other party'; 'I am struggling with this senate, who stroake the Parliament with one hand, and strike them with the other' ${ }^{72}$ The chief burgermaster certainly protected a royalist merchant who had been imprisoned by the Merchant Adventurers; and in this Bradshaw saw a litmus test of the senate's attitude. He felt that anything less than full support for the parliamentary cause would serve to increase the 'stomackfullnesse in the malignants'. More important was the arrival of the news of Ascham's murder in Spain: 'ye malignants are not a little heightened by ye report of so cruell a murther, threatening to do as much to me ere long. ${ }^{73}$

The irony is that, while the hostility of the royalists succeeded in persuading Bradshaw 'to quit the city rather than lie under such injustice and reproach', the decision to leave 'brought the senate to a consideration that they had now tried with us to the height, and that further they could not go without apparent loss of the company and making the state of England their enemy' ${ }^{74} \mathrm{It}$ is also likely that, as Bradshaw himself recognized, 'the senate's masterpiece is to keep in with your enemies to see what issue the Northern conjunction may have. They presume they can always make peace with the parliament, but the other they dare not provoke, whom they fancy will shortly have the parliament at their pleasures'. If the senate was waiting for a sign of de facto control in Britain, then by the end of 1650 they would have had good reason to curry favour with the republic.$^{75}$ Once the threat from the royalists had subsided, and the senate had begun new proceedings against Halterman, Bradshaw could begin to think about returning to England. ${ }^{76}$

\section{I I}

In the light of the murder of Dorislaus, the decision to post Anthony Ascham to Spain in 1650 seems hard to comprehend. Even though he was not responsible for the execution of Charles in any direct sense, his writings were

70 P.R.O. SP 82/7/i 84, 207v; H.M.C., Sixth report, pp. 43I-2.

${ }^{71}$ H.M.C., Sixth report, pp. 427-8. ${ }^{72}$ P.R.O. SP 82/7/197; Farington papers, pp. I 56-7.

${ }^{73}$ Farington papers, pp. I60-3; H.M.C., Sixth report, p. 428; P.R.O. SP 82/7/2 I 4. For similar complaints see P.R.O. SP 82/7/220-I, 222; H.M.C., Sixth report, pp. 428-32.

${ }^{74}$ CSPD ${ }_{1650}$, p. 562 ; H.M.C., Sixth report, p. 433. $\quad{ }_{75}$ Farington papers, pp. I63-5.

${ }^{76}$ H.M.C., Sixth report, pp. 433-44; CSPD I65o, pp. 4 I 9, 598, I65I, pp. I62, 20 I , 266, 294, 296, 452, 497, 500; Milton, Letters, p. 4I. Bradshaw spent the winter of $\mathrm{I}_{6} 5^{\mathrm{I}-2}$ in London and Chester, but returned to Hamburg at the request of the merchants in the spring of $6_{52}$, from where he progressed on official business to Denmark. There he seems to have faced renewed hostility, with plots against his person, and attacks upon his entourage. He left Denmark without success in February i653: Farington papers, pp. I69-72; Miller, Milton, pp. I34, I 52, I 56, I 58, I64, I69-70, 20 I, 2 I I; Warner, Nicholas papers, I, 320-I; Peck, Desiderata, II, 485-90; CSPV I653-4, p. 2 I. 
amongst the most prominent in urging submission to the new regime after January i 649 . He had been connected to the parliamentary authorities since his appointment as one of the tutors to the king's children under the earl of Northumberland in July i646. For his services he was awarded $\mathcal{f}_{2} 200$ in June I $649 .{ }^{77}$ Two months later he was chosen as Parker's replacement at Hamburg, in place of the suspect William Northey ${ }^{78} \mathrm{He}$ was prevented from making that journey by illness, however, and retired to his father's house in Boston. ${ }^{79}$ Upon recovering sufficiently, Ascham was sent on his fateful mission to King Philip IV of Spain, Milton having sent a letter ahead of him, pleading for safe passage. ${ }^{80}$ Armed with instructions from Walter Frost, and having already attended the Spanish ambassador, Ascham set sail from Portsmouth, although not before expressing his fear that he would go the same way as Dorislaus. ${ }^{81}$

Having narrowly escaped an attack by French ships off the Spanish coast, Ascham arrived at Porta Santa Maria in March i650, from where he complained both of his recurring illness, and of the delays in his progress towards Madrid. ${ }^{82}$ He was met by the duke of Medina, who provided him with accommodation, and who told him that he could not progress until he received word from the king. ${ }^{83}$ Ascham feared that the delay was a deliberate ploy by the duke, and made independent arrangements to notify the king of his arrival and intentions ${ }^{84}$ Orders were eventually given that he could progress towards Madrid on io April, but he was then delayed not by the Spanish but by a relapse in his own health. He wrote to the council of state of the 'prison' in which he was forced to rest, and that his strength was decaying daily. ${ }^{85}$ Ascham eventually set out for Madrid in mid-May, stopping in Toledo and Seville, where he was entertained by an English merchant, arriving at Madrid in early June. Fearing for his safety, Ascham seems to have had, at his own request, an escort from the king's cavalry. ${ }^{86}$

Like Montrose, Francis, Lord Cottington and Sir Edward Hyde were

${ }^{77} \mathrm{~J}$. Milton, Complete prose works (New Haven, I 966), Iv, 647; Cf vi, 2 I 6; Lf viII, 446; CSPD I649-5o, p. 483; P.R.O. SC6/Chas. I/ I667 m.ı Ir.

${ }_{78}$ CSPD I649-5o, p. 288; P.R.O. SP 46/95/185-86v; Milton, Complete prose works, v, 507-10.

${ }^{79}$ P.R.O. SP $94 / 43 /$ i 9.

${ }^{80}$ Milton, Letters, pp. I0-I 3 ; CSPD I649-5o, pp. 482, 488, 598; P.R.O. SP 2 I/29/ i 94; G.U.L. Mm.I.46, p. I40; H.M.C., Thirteenth report, appendix I, p. 5 I8; CF vi, 353.

${ }^{81}$ CSPD ${ }_{1} 649-50$, pp. 489, 492, 494, 496, 498, 502, 569, 598; P.R.O. SP 2 I /29/ $195 ; C f$ vi, $35^{6}$; P.R.O. SP 94/43/69; Guizot, History, I, 202, 36 I-2.

${ }^{82}$ P.R.O. SP 94/43/25; The process and pleadings in the court of Spain upon the death of Anthony Ascham (London, I65I, reprinted in Harleian Miscellany, vi, London, I8 10), p. 238. It was said that Ascham suffered 'a great pain of cholic, with a callenture and vomiting': Thurloe SP, I, I 49-5 I.

${ }^{83}$ Medina wrote to the king on 27 March: Process and pleadings, p. 238.

${ }^{84}$ P.R.O. SP 94/43/27; H.M.C., Thirteenth report, appendix I, p. 52 I ; C.U.L. Mm. I.46, p. I 49

${ }^{85}$ P.R.O. SP 94/43/29, 3I-2, 70; CSPV I647-52, p. I 45; CIf vi, 407; CSPD I65o, pp. I 36, 576; Process and pleadings, p. 238. M. Gonzalez-Arnao, 'El embajador de Cromwell asesinado en Madrid', Historia I6, Lxxxir ( I983), 32, claims that Ascham was treated with a great deal of respect upon his arrival.

${ }^{86}$ P.R.O. SP 94/43/7ov; CSPV I647-52, pp. I 46-7; Process and pleadings, p. 238. He was escorted by Moreda, three captains, an ensign, and a sergeant-major: Gonzalez-Arnao, 'El embajador', p. 32 . 
charged with special duties in relations with European powers. ${ }^{87}$ Their instructions included the order to contract loans with English merchants in Spain, and Hyde wrote a circular letter asking 'that all Princes and States will be firm and united to assist the Prince in taking the highest vengeance on this transcendant villany'. He hoped the regicide would 'put new fire of honest rage and fury into us... to take and follow those courses and counsels which are most likely to take vengeance upon those incurable rebells' ${ }^{88}$ Cottington remarked, in early June I65o, that they were well received, and that Charles II was 'as much honoured as we can desire; but I doe translate to them the old English proverbe, viz. lesse of their courtesie, and more of their purse'. Together they worked to secure the favour of prominent courtiers such as Don Luis de Haro, and addressed the king himself, in addition to their approaches to the merchants. ${ }^{89}$ That they feared the council of state would spoil their plans, however, is clear from Cottington's statement that 'all the world is afraid of provoking those rebels, as we find by experience in this place'. ${ }^{90}$ Ascham was an obvious threat to the ambassadors' plans to raise supplies for Ireland, as Hyde expressly affirmed, and his move to Spain was noted by royalist newswriters. They also noted that he was the author of a book justifying the new regime. Cottington related the news of Ascham's arrival to Edward Progers in late April, after which the ambassadors urged King Philip not to receive him. It was widely recognized, however, that their attempts to block Ascham's progress by diplomatic means were doomed to failure. ${ }^{91}$ One account from Spain, published in London on 20 June I650, claimed that

Your Parliament agent is but lately arrived, and had all the respects and formalities that a soveraign minister of state could expect, he had two audiences the first three days he came, one public, the other private, with Don Luis de Haro, the favourite, who swaies

87 For their Madrid embassy see: Bodl. MS Rawlinson C 726 ; R. Ollard, Clarendon and his friends (Oxford, I 988), pp. I 34-40; and M. J. Havran, Caroline courtier. The life of lord Cottington (London, I973), pp. I64-8 I. Other courtiers in Madrid included Sir Richard Fanshawe and Lord Goring: B. Marshall (ed.), Memoirs of Lady Fanshawe (London, I905), pp. 95-io I.

${ }^{88}$ Macray, Calendar, II, I 3 ; State papers collected by Edward, earl of Clarendon (3 vols., Oxford, I 773, hereafter Clarendon state papers), II, 48 I ; B.L. Add I 5856, fos. 20-20v; Ogle and Bliss, Calendar, I, 465 ; B.L. Add I 8982, fos. I 77-8. Sir Richard Browne commented on the offers of help from Spain soon after the ambassadors' arrival, and of talks regarding a treaty between the two crowns: B.L. Add I 2 I 86 , fos. $67 \mathrm{v}, 7$ I.

89 Clarendon state papers, II, 502, 504-6, 507; Macray, Calendar, II, 35; Cottington to Edward Proger, in S. H. A. Hervey, 'Edward Proger', West Stow parish registers (Woodbridge, i 9o3), p. I94; and in H.M.C., Tenth report, appendix IV (London, I885), pp. I46-9. For the ambassadors' message to Philip, which mentioned Ascham's arrival, and the cool response of the Spanish, see Guizot, History, I, 42 I-5. Don Luis was attempting to treat with Mazarin at this time: B.L. Add I 2 I 86, fo. I 2 I v. Cottington and Hyde sought a Franco-Spanish alliance, but the Spanish suspected that the ambassadors were merely agents of the cardinal. The French, meanwhile, were playing the typical 'waiting game' regarding England, and were watching Spain anxiously. As we might expect, French attitudes towards England began to alter in late i6 $65^{\circ}$ : P. A. Knachel, England and the Fronde (New York, I967), pp. I 20, I33-4, I46, I48, 2 I9-2 I ; Guizot, History, I, 40 I, 408-I I.

90 B.L. Egerton 2534, fo. I 6.

91 H.M.C., Tenth report, appendix IV, pp. I 46-9; Macray, Calendar, II, 44, 54, 55, 6o, 6 I ; Ogle and Bliss, Calendar, I, 463; Bodl. MS Rawlinson C 726, fos. 86v-87v; Bodl. MS Clarendon 39, fo. 2 I6; CSPV ${ }_{16} 67^{-52}$, p. I 43 ; Warner, Nicholas papers, I, I 72 ; Gonzalez-Arnao, 'El embajador', p. 32. 
most; and though this agent be of a complexion that the Spaniards do hate, for they paint Judas alwaies with red hair, yet there hath been the least affront or indignity offer'd him yet. ${ }^{92}$

By the time his news was published, however, the Spanish correspondent had already been disproved on this last point, probably because his other claims were accurate. Ascham reached Madrid on Whit Sunday, 'an omen portending that he would speedily repent of his coming', as the Venetian ambassador mused. By the following evening, 'that ingenious honest gentleman' was dead. ${ }^{93}$ It seems that Ascham, who was under the superintendence of Don Diego de Moreda (the appointee of the duke of Medina) was lodged in a 'common inn' in the Cavalero de Grava; ' there being neither lockes nor boltes on the Doores or Windowes'. It is alleged that Ascham had to be plied with alcohol to make him accept such accommodation. At six o'clock on the morning following their arrival, Ascham's interpreter went to announce his arrival, and to complain to Jeronimo de la Torre (secretary of state) about the lodgings. '[I]t was observed there passed by some that went muffled thereabouts, who were overhead to say essos son, these are they'. The secretary promised a guard, but before he could reach the king, Ascham was dead. ${ }^{94}$

The six men responsible for the murder were: John Williams, William Sparke, Henry Progers, Valentine Progers, Edward Halsall, and William Arnett. Of these six men who approached Ascham's posada on the night of 6 June, four guarded the stairs, while two entered the envoy's chamber. Approaching the table, William Sparke pulled off his hat and said, 'Gentlemen, I kiss your hands, pray which is the resident?' As Ascham rose, John Williams grasped him by the hair and ran him through the temple with a small 'stilletta', after which Sparke added a further four wounds. Before they fled, the two men also murdered his interpreter, although not before sustaining injuries themselves. Leaving the inn, five of the murderers took sanctuary in the nearby hospital of Santa Andreas, while Henry Progers separated from the rest and went to the house of Basadona, the Venetian ambassador. The latter, who was entertaining guests, offered Progers only temporary shelter, as a favour to his friends Cottington and Hyde. After one night there, Progers escaped to the house of his employer, Cottington, and eventually fled to France and safety. ${ }^{95}$ Within half an hour of the murder, the five men were removed from the apparent safety of the church, and taken to prison by the alguaciles. Edgeman,

${ }_{92}$ T. B, Extraordinary Newes from the Court of Spain (London, I650), pp. I 2-I 3.

${ }_{93}$ Process and pleadings, p. 239; CSPV I647-52, pp. I47-8; Mercurius Politicus, no. 2 (I $3^{-20}$ June I65o), pp. $3^{2-3}$.

94 Thurloe SP, I, I 49-5 I, 202-4; Mercurius Politicus, no. 2 (I 3-20 June I65o), pp. 32-3; Macray, Calendar, II, 65-6; Clarendon state papers, II, 542-3; P.R.O. SP 94/43/35-37v; Process and pleadings, p. 239. Ascham's secretary Fisher, himself the son of a former resident in Madrid, sought the help of Lawrence Chambers and William Marston, who offered a far more sumptuous residence: Gonzalez-Arnao, 'El embajador', pp. 32-3. It was claimed by some that the murderers spoke with Riva on the morning of the attack: Process and pleadings, p. 244.

${ }_{95}$ Peck, Desiderata, II, 456-7; P.R.O. SP 94/43/7 I ; Thurloe SP, I, I 49-5 I ; Gonzalez-Arnao, 'E1 ambajador', pp. 34-5; Whitelocke, Memorials, III, 204. For the account in the journal of Hyde's secretary, see Bodl. MS Clarendon I 37 , fos. 26v-27. 
Hyde's secretary, claimed that they were imprisoned with 'much shew of rigour, though all the towne comended the accon'. ${ }^{96}$ There ensued much wrangling, because the pope's nuncio (Julio Rospigliosi, later Clement IX) claimed that they could not legally be removed from a religious sanctuary. Eventually, after Valentine Progers had died in custody, all were proceeded against and condemned to die. All but William Sparke, a merchant with royalist sympathies, were to escape, however, and Sparke alone was executed in $1654 \cdot{ }^{97}$

Halsall, Arnett and Williams were all soldiers serving with the king of Spain. Halsall, a member of the garrison in Lathom House during the Civil War, returned to England after fleeing Madrid, and was involved in further conspiracy in Lancashire in 1655 , before fleeing to the continent again in I $656{ }^{98}$ His brother was another active conspirator, suspected of planning to murder Cromwell, who was eventually betrayed by his servant, one of Thurloe's spies. ${ }^{99}$ Arnett, a Scot from Crawford's regiment, re-emerged at Cologne (as a page in the exiled court) in I655 at the same time as Williams, when he was banished for beating an equerry in the king's presence. ${ }^{100}$

The vital question concerning Ascham's death is the possible involvement of Cottington and Hyde, and the most obvious evidence is that Henry Progers was in the ambassadors' service. Both the Progers brothers are recorded in Edgeman's journal of the royal embassy to Spain from November i $649 .{ }^{101}$ The envoys certainly thanked the Venetian ambassador for sheltering Progers, and covered his tracks until it was safe to move to France. ${ }^{102}$ The confession made

96 Bodl. MS Clarendon $\mathrm{I} 37$, fo. 27.

97 Peck, Desiderata, II, 456-7; CSPV I647-52, pp. I 47-8; P.R.O. SP 94/43/73; Abbott, Cromwell, III, 203; Macray, Calendar, II, 63, I I 4. Sparke, the only protestant among the prisoners, had written Nudae veritatis confidentia in se defendendo, in defence of his case, and claimed that some official conspiracy ensured that he alone was executed: Gonzalez-Arnao, 'El embajador', p. 38. He also wrote a desperate letter from Madrid in March I653; S. H. A. Hervey, 'The Proger brothers', in West Stow parish registers (Woodbridge, i 903 ), p. 228.

98 G. Smith, 'The royalists in exile I640-1660' (unpublished Melbourne University PhD thesis, I99I), p. 78; Newman, Royalist officers, p. I 73; D. Underdown, Royalist conspiracy in England (New Haven, i 960$)$, p. I 48.

99 Newman, Royalist officers, p. I 74; F. J. Routledge (ed.), Calendar of Clarendon state papers, vol. 5 (Oxford, I970), passim; Underdown, Royalist conspiracy, pp. 65, I32-3, I 70-3; E. Scott, The travels of the king (London, I 907), pp. 66-8, I 25, I 29-37; W. D. Macray (ed.), Calendar of Clarendon state papers, III (Oxford, I876), I6, 4I, 44, 49, 58-9, 68, 74, 87, I I 5, 4I4; B.L. Egerton 2542, fo. I 38 .

100 Thurloe SP, III, 458, 532, IV, I 22 ; CSPD I655, p. 390; Macray, Calendar, III, 29, 65; Smith, 'Royalists in exile', pp. 78-9. $\quad 101$ Bodl. MS Clarendon I 37, fos. 20v, 2 IV.

102 Peck, Desiderata, II, 456-7; P.R.O. SP 94/43/7 I CSPV I647-52, pp. I 47-8; Clarendon, History, v, I36-9. References to 'Progers' abound in royalist papers, although at least some of these refer to Arthur Progers (servant to Sir Henry Bruce, gentleman of Charles I's privy chamber); to Edward Progers; and to James Progers: H.M.C., Fifth report (Nendeln, I979), p. 35 I ; Ogle and Bliss, Calendar, I, 3 I 4-I5; B.L. Add 37047, fo. 6; Clarendon state papers, II, 5 I o; Macray, Calendar, II, I 5, 45, 50, 69, 77, 85, 98, I 42, 258, 3 I 7, 386; Warner, Nicholas papers, I, 206-7, 296; The Genealogists, n.s. Xxv (i go9), 243. Most of the Progers family were courtiers. James Progers had been governor of Abergavenny, and joined Cottington and Hyde in Madrid. Henry seems to have rejoined the court, became an equerry, was knighted in I 684, and became sergeant porter to the king. He died in I687: Hervey, 'Proger brothers', pp. 223-30; Thurloe SP, III, $45^{8}$. 
by the murderers, when captured by the Spanish authorities, claimed that they had been acting upon information, sent to them from within the exiled court in France, that Ascham was travelling to Spain to sign a treaty with King Philip. ${ }^{103}$ Perhaps their informant was Edward Progers, the elder brother of two of the murderers, who was clearly writing to Cottington from Paris and the Hague, and who intended some of his messages for his brothers. Edward Progers was a page, and later groom, of the bedchamber to both Charles I and Charles II. By i 650, he was aligned with Hyde's faction in the exiled court, and in correspondence with both the ambassadors in Spain and with Montrose, Hamilton, and Prince Rupert. ${ }^{104}$ He had been a close confidant, and travelling companion of Charles II since the late I640s, and gained the reputation of being the king's 'pimp', and one who 'helped to debauch' the young monarch. He was certainly a 'confidant of all his intrigues', and linked to his 'dubious episodes'. Progers was arrested following Penruddock's rising, and re-emerged as a courtier, and M.P., at the Restoration. ${ }^{105}$

The murderers' statement forces us to examine the comments made by Hyde regarding the murder, and the ambassadors' actions in Spain. Since it was immediately apparent that Progers was a servant of theirs, the two envoys wrote that they were 'like to have trouble and vexation enough' from the affair. They plainly endeavoured to 'exculpate themselves from all complicity', and the Venetian ambassador claimed that 'the belief in their innocence is practically universal' ${ }^{106}$ Hyde told Nicholas that 'we knew not of that man's being come to the town until we heard that he was dead', and informed Charles II that:

We cannot find by any enquiry we can make that the persons engaged in the bold attempt upon Ascham had digested it amongst themselves in any former deliberation; but met accidentally at that time near the lodging, and as passionately rushed into it; which may easily be believed by the little care they took to secure themselves, which for two hours space they might easily have done; and by their choosing the next little church to retire to, amongst so many convents and other privileged places, from whence they would with great difficulty have been removed.

This differs not only from the confession of the murderers themselves, but from Cottington's statement in April I650, and the account in Hyde's History. There, he claimed that Ascham's audience had been granted by the king, and that the murderers knew of his arrival. They had, he related, planned to meet Ascham outside Madrid, but upon missing him, discovered where he was staying and

103 Thurloe SP, I, I 49-5 I.

104 B. D. Henning, The house of commons I66o-i6go (3 vols., London, I983), III, 293-4; Hervey, 'Edward Proger', pp. I9I-222; The European Magazine (May I 798), pp. 297-99; (June I 798), pp. 372-4; (July I 798), pp. I6-I 7; (Sept. I798), p. i69; H.M.C., Tenth report, appendix IV, pp. I $46^{6-9}$. I am grateful to Mr Nigel Arnold-Forster for providing not merely information regarding Progers, but copies of manuscripts in his possession.

105 Smith, 'Royalists in exile', pp. I 56-63; B.L. Harl. 6804, fo. 254.

106 Macray, Calendar, II, 63; CSPV I647-52, pp. I47-8; P.R.O. SP 94/43/7 Iv. 
proceeded with their plan. ${ }^{107}$ Cottington had told the brother of two of the assassins about Ascham's arrival, and the two ambassadors had informed King Philip, on I9 April. ${ }^{108}$ This accords with the contemporary claim that the murderers, who had sworn a solemn oath to destroy Ascham, were watching him as he arrived at the inn on the Sunday evening, having met in the tavern 'de la Redde San Luis' nearby. ${ }^{109}$ Edgeman himself clearly recorded how he had 'met Ascombe the Rebells agent in a litter coming into the Towne' on Whit Sunday. ${ }^{110}$ Hyde also changed his tune over the legality of taking the murderers from their sanctuary. In ${ }^{6} 5_{5}$ o he had composed a paper in which he not only justified the murder, saying it was 'lawful for any man to kill him', but maligned the way in which the murderers were held captive. Later, he wrote that those who denied the legality of sanctuary in cases of murder were correct all along. ${ }^{111}$

Hyde would have had good reason to be economical with the truth in $165^{\circ}$ since, as he later affirmed

They were both in extraordinary trouble and perplexity... Though they abhored the action that was committed, they foresaw the presence of one of their own servants in it, and even some passionate words they had used in their expostulation with don Lewis against the reception of such a messenger... would make it believed by many that the attempt had not been without their consent or privity. ${ }^{112}$

Whether or not he did have a role in the murder may never be known for certain, but if he was sincere and truthful, then an explanation may run as follows. We know that Cottington and Hyde held conversations with Don Luis de Haro before Ascham's arrival, and secured his assurance of allegiance to Charles II. Furthermore, they had made it plain to him, in strong language, that they opposed Ascham's mission. Finally, we know, from Hyde's own statement, that de Haro kept a keen trace on Ascham's progress towards Madrid. If Cottington and Hyde really did have nothing to do with the plotting, then their Spanish friend may well have done. Don Luis de Haro, a nephew of Olivares, was called by some 'the evil finger'; he was one of the key ministers of King Philip's court, and by r 648 held a powerful position in Spanish politics. It was de Haro, of course, who expressed the famous comment that Spain was 'envious of such faithful subjects' as those who had murdered Ascham; it was to de Haro that the murderers sent word of their success upon reaching the safety of the church; and it was de Haro who sought to reassure the ambassadors regarding the prisoners' plight. ${ }^{113}$ It is quite clear that de

107 Macray, Calendar, II, 64; Clarendon state papers, II, 542-3; Clarendon, History, v, I 36-9.

108 Hervey, 'Edward Progers', p. I97; Bodl. MS Rawlinson C 726, fos. 86v-87v.

109 Process and pleadings, p. 244; Gonzalez-Arnao, 'El embajador', p. 34.

110 Bodl. MS Clarendon I37, fo. 26v.

111 Macray, Calendar, II, 63-4; Clarendon state papers, II, appendix, pp. lxvi-lxix; Clarendon, History, v, I $3^{6-9}$.

112 Clarendon, History, v, I $36-9$.

113 Clarendon state papers, II, 502; Clarendon, History, v, I $36-9$; CSPV ${ }_{1} 647^{-52}$, pp. I 48-9; Thurloe $S P$, I, I 52; R. A. Stradling, Philip IV and the government of Spain I62I-I665 (Cambridge, I988), pp. I 70, 246-68; J. H. Elliott, Imperial Spain I469-17I6 (London, I963), pp. 346-7; GonzalezArnao, 'El embajador', p. 35; Bodl. MS Clarendon i 37, fo. 29. 
Haro was the man most trusted at court by Cottington and Hyde, as appears from the large volume of correspondence between them. ${ }^{114}$

Whatever the ambassadors' involvement in Ascham's murder, their role after the event can be in little doubt. Referring to the murder as 'this odd accident', they told Robert Long that they were hopeful of the prisoners' escape, and that they were not afraid of 'interceding, and even expostulating' in the affair. ${ }^{115}$ They dispatched Edgeman to the palace on their behalf, and sought to slight the reputation of Ascham and his associates. ${ }^{116}$ John Baptista de Rivas, his interpreter, was accused of being 'a renegade friar'; Ascham himself was accused of showing 'uncleanly liberty throughout their journey'; and George Fisher was styled 'a very silly secretary'. Not unexpectedly, they made much of the medal discovered around Ascham's neck, which even Fisher admitted 'did much redound to the disgrace of Mr Ascham'. ${ }^{117}$ More importantly, 'out of charity and compassion, Hyde and Cottington send meat every day to the gentlemen who were imprisoned for Ascham's murder, who would otherwise be starved'. They kept a close eye on proceedings against the 'poor prisoners', whose captivity was 'very strict and their misery great'; they even delayed their departure from Madrid to ensure the continued protection of the prisoners. When they could stay no longer they ensured that the cardinal of Toledo observed the interests of the remaining villains. ${ }^{118}$ Later, upon an appeal from William Sparke that the prisoners were 'loaded and oppressed with irons and unusual cruelties, and almost starved', an attempt was made by Charles II to ensure that they should not 'be suffered to perish in prison by famine or too severe usage'. ${ }^{119}$ Lastly, in July i653, Halsall, Sparke and Williams wrote to Hyde from their prison, to thank him as one, 'who hath been all along so much our tender patron'. ${ }^{120}$

As we might expect, the government in London made much of the murder of another of their agents. Its mouthpiece newspaper, Mercurius Politicus, exclaimed that the event showed 'of what spirit the old cavalier party still are', and the author of Politicus, Marchamont Nedham, would later claim that the murder of Ascham, like that of Dorislaus, was the direct responsibility of Charles II. Ascham's secretary, meanwhile, kept the council informed of daily events in Madrid, under the protection of an armed guard for his own safety. He wrote that, 'I dare not strive out of doores, soe many English, Irish, and

114 Bodl. MS Rawlinson C 726.

115 Macray, Calendar, II, 64-6; Clarendon state papers, II, 543-4.

116 Bodl. MS Clarendon I37, fo. 28.

117 Macray, Calendar, II, 65-6; Clarendon state papers, II, 542-3; P.R.O. SP 94/43/76; CSPV I647-52, p. I 49; Process and pleadings, p. 245. The medal (a copy of the engravings upon which may be found in I. Coltman, Private men and public causes (London, I962), facing title page) bore an inscription consisting of a crown stabbed with a dagger, and 'XII O.B.S. Newarke, I646'. Contemporary accounts misrepresented these words as Nebart and Obstricti, and concluded them to be a reference to 'those twelve, which gained Nebart, and occasioned the wars... that he came to deceive' (Process and pleadings, p. 245). While the true meaning is obscure, it probably referred to the surrender of the king at Newark in 1646.

118 Macray, Calendar, II, 67, 77, 84, 98, I I 4; Clarendon state papers, III, 23-4; CSPV I647-52, p. I 7 I. 119 Macray, Calendar, II, I03. $\quad 120$ Bodl. MS Clarendon 46, fo. 6. 
Scotch discontented persones are in this city, and those soe desperate and resolute, that they valew not their own lives'. ${ }^{121}$ He received orders from London to return with the agent's body, and letters of complaint to deliver to the king. The council, noting that Ascham had been 'foully and criminally stabbed', called for hasty punishment of all 'sponsors and accomplices'. They also claimed that the murder 'utterly subverts the very foundation of correspondence and commerce', and warned that continued friendship depended upon justice being seen to be done. Furthermore, orders were drawn up, 'that out of those persons who have been in arms against Parliament, not being admitted to compound, and are in the power of Parliament a certain number be speedily proceeded against to trial for their lives upon occasion of the assassination of Mr Ascham ... and of his interpreter'. The intended victims of parliament's revenge included Sir John Stowell, David Jenkins and Walter Slingsby. ${ }^{122}$ While the Spanish authorities had jailed Don Diego de Moreda for his slackness in ensuring Ascham's safety, those at Westminster were outraged at the prospect that 'the privilege of the whore of Babylon' would stand 'in competition with that privilege of indemnity to public agents, which is annexed as a label to the law and custom of nations', and that the murderers would be released back to the sanctuary of the church from which they had been taken. ${ }^{123}$ They even ordered their hack, Nedham, to issue a response to a Spanish piece in defence of the murder, while the official printer issued The process and pleadings in the court of Spain in connection with the case. ${ }^{124}$

Although Fisher continued to complain of the danger from 'some ten Cottingtonians' who were tracking him down, and despite the delays in his return to England, it once more became apparent that the murderous plots of the royalists had proved counterproductive. The Spanish clearly worried that the affair would have adverse implications for the safety of Alonso de Cardenas, their ambassador in London, and warned the ambassadors that their safety would be imperilled if he came to harm. ${ }^{125}$ Secretary Nicholas noted that 'our Spanish ambassadors are strangely mute, and I doubt their business goes ill'. ${ }^{126}$ The council had intimated that commercial relations would suffer in the absence of justice, and they also exploited the victory at Dunbar. Once again a dithering European government was encouraged to take sides only as it became clear on which side fortune smiled. As the Venetian ambassador noted, the affair was ruled by 'the dictates of policy', adding that, 'might generally

\footnotetext{
121 Mercurius Politicus, no. 3 (20-27 June I650), p. 37; M. Nedham, A true account of the late bloody and inhumane conspiracy (London, I654), p. I9; CSPV I647-52, p. I49; CSPD I65o, p. 209; Thurloe SP, I, I $48-9$, I 52-3; Cf $\mathrm{fI}, 428$.

122 CSPD I650, pp. 2 I8, 220; Milton, Letters, pp. I9-22, 32-3; Milton, Complete prose works, v, 523-4; CF vi, 434; Gonzalez-Arnao, 'El embajador', p. 36. Further insult was added by the shoddy way in which Ascham's body was being cared for: P.R.O. SP 94/43/73v, 78 .

123 Mercurius Politicus, no. 3 (20-27 June I65o), p. 38; Clarendon state papers, II, 542-3; Mercurius Politicus, no. 6 ( (1 I-18 July i650), p. 84; CSPV I647-52, p. I 55 .

${ }^{124}$ CSPD ${ }_{1} 650$, p. 387 ; Process and pleadings.

${ }^{125}$ CSPD I650, p. 253; Thurloe SP, I, I57; CSPV 1647-52, pp. I47-8; Clarendon, History, v, I36-9. For Cardenas, see A. J. Loomie, 'Alonso de Cardenas and the Long Parliament I640-1648', English Historical Review, xGVII (I 982), 289-307. ${ }^{126}$ CSPD I650, pp. 287-8.
} 
prevails over right'. Admiral Blake's Iberian victories, and his imposition of a humiliating peace upon Rupert, demonstrated 'how the commonwealth intended to treat countries that harboured disrupters of English commerce'. Shortly after Blake's triumph, King Philip granted access for English ships to Spain's ports, and granted recognition to the commonwealth itself. The new mood in Spain was epitomized by the duke of Medina, among the most proEnglish of the Spanish court. Worried greatly about the danger of alienating London, he expressed reluctance to recognize Charles II, and led those who urged the king to prosecute Ascham's murderers. He would counsel concessions to the commonwealth and protectorate right up to the war with Britain in I655. Once 'the straight and fair path' was 'deserted for that of profit and advantage', the Venetian ambassador noted, 'open hostility against Charles II' grew, and his ambassadors were asked to leave Madrid. 'The comedy was over.' ${ }^{127}$

Fisher, the 'silly secretary', was astute enough to exploit such developments; telling the Spanish of the threat to friendly relations between the two nations, and reminding them that England and Spain shared common enemies in Portugal and France. He told his employers in London that 'if the Parliament strike the iron whilst it is hott, they may procure anything of this king. The cavalliers little think that by Mr Ascham's death they have spoyled theire own business.' In this, at least, he proved in agreement with the later musings of Hyde himself. ${ }^{128}$ In November i 650 , Fisher was able to report that the king was stepping up his efforts to proceed with the trial of the prisoners, and that 'no diligence was wanting' on his behalf to secure successful prosecution. Philip even wrote to parliament, expressing his regret over Ascham's murder, while Alonso de Cardenas told parliament of the 'lively resentment' concerning the murder, and that everything possible was being done, even in opposition to the wishes of the ecclesiastical judges. 'The case', he said, 'could not be pressed more if the dead person were a Prince, heir to the crown of Spain. ${ }^{129}$ That the affair rumbled on was probably more a product of Philip's difficulty in confronting Rome and domestic opinion over the sanctuary issue, than an

\footnotetext{
${ }^{127}$ CSPV I647-52, pp. I58, I63-4; R. Brenner, Merchants and revolution (Cambridge, I993), p. 58 ; Stradling, Philip IV, pp. 349-5 I ; R. A. Stradling, 'A Spanish statesman of appeasement: Medina de las Torres and Spanish policy, I639-I670', Historical fournal, xix (I976), I3-I4; Gonzalez-Arnao, 'El embajador', pp. 36-8; Knachel, Fronde, p. 22 I. Hyde told Nicholas that Cottington was 'more contemned and hated here than Nicholas can imagine': Macray, Calendar, II, 88. The ambassadors' departure from Madrid seems to have been somewhat hurried, and the two men appear more than a little disgruntled: B.L. Add I 2 I86, fos. 22 I, 24IV, 249; Bodl. MS Clarendon 4I, fos. 97, I 25. Sir Richard Browne noted that the attitude of the French changed at precisely this time, and in the light of the possibility of an Anglo-Spanish détente, which 'gives them here great jealousies, and constraines them to proceed very tenderly with those powerfull rebbells': B.L. Add I I 86, fo. 209. The Spanish thought 'it would be inexpedient to make any formal declaration ... until it is known with greater certainty what course things will take', and that Spain should act 'without any fixed principle'. They thought Cottington's arrival would be an 'inconvenience', and tried to prevent his journey: Guizot, History, I, 37 I-8, 384-94, 398, 404-5, 420, 427-8. ${ }^{128}$ P.R.O. SP 94/43/4 I-3; Thurloe SP, I, I 54-5; Macray, Calendar, II, I03-4.

129 P.R.O. SP 94/43/4 I-3; CSPV I647-52, p. I 57 ; CSPD I650, pp. 400, 439; H.M.C., Thirteenth report, appendix I, pp. 544, 547; G.U.L. Mm. I.46, pp. I50-2; Peck, Desiderata, II, 456-7.
} 
expression of his being a 'meere neutralist', more afraid of parliament than respectful towards it, as Fisher proclaimed. ${ }^{130}$ That the king was vacillating seems clear from the fact that while he had continued with the legal proceedings, he said that 'there must be no unseemly haste, and no reason of state shall cause more to be done than is just and proper'. ${ }^{131}$ Such irresolution not only mirrored the problem of alienating various strands of domestic and foreign opinion, but his attempt to play off against each other the factions within his own court, represented by de Haro and the duke of Medina. ${ }^{132}$

In the end, Fisher summed up the situation in saying that 'Mr Ascham's murderers will surely die in prison, for the king cannot put them to death and yet he will not release them', and little was there to do but maintain the protests (which continued until I655), and offer relief to Ascham's family. His ageing father, two unmarried sisters, and brother John were awarded payments and offered employment in r 652. In a last symbolic gesture, their kin's murderers were excepted from the Act of Oblivion. ${ }^{133}$

\section{V}

The murder and intimidation carried out by agents and ambassadors of Charles II during I 649-50 was heavily couched in the language of revenge for the part played by the victims in the execution of Charles I, whether in terms of the events preceding and promoting the trial, or the justifications which followed it. The impression that such incidents were undertakings of summary justice by rogue villains driven by personal rage has been perpetuated by the fact that the men chosen by the commonwealth to represent its interests abroad were men towards whom the aggrieved cavaliers would have had cause for hostility, and by the fact that the attacks appeared to have been badly planned. Closer analysis reveals, however, that the assailants were closely connected to exiled courtiers of the new king, and that their plots were a good deal more organized than has hitherto been presumed. More important is the suggestion that their attacks were motivated by more than mere revenge, and that they

130 P.R.O. SP 94/43/65-7, 69-82; CSPD ${ }_{1} 65^{I}$, pp. 6, 7, I9, 26o, 305, 447, 484, I6 $5_{5}{ }^{-2}$, pp. 95 , I 45, 486; H.M.C., Thirteenth report, appendix I, pp. 553-4; H.M.C., Seventh report (Nendeln, I979), p. 76; CSPV 1647-52, pp. I 70, I 74-5, I83, I86, I91; Macray, Calendar, II, I03; Thurloe SP, I, I89.

${ }^{131}$ Stradling, Philip IV, pp. 349-50; Guizot, History, I, 363-7. Pressure to punish the murderers came from Alonso de Cardenas in London, who was a friend of the new regime, and who felt little for Charles I or his son, from the duke of Medina, and from the fear that lack of punishment would prevent them from hindering an Anglo-Dutch alliance: Guizot, History, I, 362-3, 368-9, 427-8, $4^{66-7 \mathrm{r}}$.

${ }^{132}$ Stradling, Philip IV , pp. 254-7, 259, 262-3, 349-51; Stradling, 'Spanish statesman', pp. I-3 I. It is interesting that Haro's spending spree on items from Charles I's private art collection was halted with the recognition of the new regime: J. A. Loomie, 'New light on the Spanish ambassador's purchases from Charles I's collection, I649-I653', Journal of the Warburg and Courtauld Institutes, LII (I989), 257-67.

${ }_{133}$ P.R.O. SP 94/43/I05, I I Iv; CSPD I65I, p. 505, I65I-2, pp. 4I, 93, I07, 3 I4; CJ viI, I46; Abbott, Cromwell, III, 878-9I ; Gonzalez-Arnao, 'El embajador', pp. 39-40. As late as April i65 I Sir Richard Browne reported that Westminster was threatening that unless the murderers were executed peace between the two nations could not be ensured: B.L. Add I 2 I 86, fo. 248. 
represented attempts to remove the men who stood in the way of Charles II's foreign policy objectives. The thuggery of the royalists achieved little, and even proved counterproductive, serving to foster some otherwise lacklustre sympathy from European dignitaries. The final point worth stressing in the light of this evidence, is the extent to which Europe's leaders played a waiting game with their British neighbours, avoiding hasty commitments to either side until it became clear precisely which party was likely to prove predominant. ${ }^{134}$

134 This may in part have been prolonged by the false reports reaching the continent from Britain, which initially convinced the exiles that Cromwell was suffering militarily in both Ireland and Scotland. See for example Sir Richard Browne's comments: B.L. Add I 2 I 86, fos. 7 I-72v, 77. 